Institute of $\mathbf{F}_{\text {ood and }} \mathbf{A}_{\text {gricultural }} \mathbf{S}_{\text {ciences }}$

\title{
Florida Solid and Hazardous Waste Regulation Handbook: Hazardous Materials Transportation Authorization Act (HMTAA) 1
}

Michael T. Olexa, Aaron Leviten, and Kelly Samek²

\section{What Is the Hazardous Materials Transportation Authorization Act (HMTAA)?}

In 1994, Congress enacted the Hazardous Materials Transportation Authorization Act (HMTAA) to provide protection against the risks to life and property during the transportation of hazardous materials. HMTAA broadened the regulatory and enforcement authority of the Secretary of Transportation. The statute is so comprehensive that it covers the transportation of hazardous materials by:

- aircraft.

- rail.

- ships.

- vehicles.

\section{What Are the Requirements of HMTAA?}

HMTAA requires that all hazardous material employers train their employees in:

- handling.

- loading.

- storing.

- unloading.

- transporting.

- emergency prepardness.

The Secretary has discretionary power to require anyone who transports hazardous materials to register with the Department of Transportation (DOT). However, some transporters have a mandatory obligation to register with DOT. These include:

1. This is EDIS document FE449, a publication of the Department of Food and Resource Economics, Florida Cooperative Extension Service, UF/IFAS, University of Florida, Gainesville, FL. Published December 2003. Please visit the EDIS website at http://edis.ifas.ufl.edu.

2. Michael T. Olexa, Professor in the Department of Food and Resource Economics and Director of the Agricultural Law Center, Florida Cooperative Extension Service, UF/IFAS, University of Florida, Gainesville, FL, and Member of the Florida Bar and Chair of the Agricultural Law Committee of the Florida Bar; Aaron Leviten, Attorney in Orlando and guest lecturer on pesticide litigation at the University of Florida; and Kelly Samek, 2003 graduate of the Levin College of Law at the University of Florida.

The Institute of Food and Agricultural Sciences is an equal opportunity/affirmative action employer authorized to provide research, educational information and other services only to individuals and institutions that function without regard to race, color, sex, age, handicap, or national origin. For information on obtaining other extension publications, contact your county Cooperative Extension Service office. Florida Cooperative Extension Service/Institute of Food and Agricultural Sciences/University of Florida/Christine Taylor Waddill, Dean. 
- anyone who transports a

highway-route-controlled quantity of radioactive material.

- anyone who transports more than 25 kilograms (55 pounds) of certain explosive materials by motor vehicle, rail car, or transport container.

- anyone who transports more than 1 liter (1.06 quarts) of a material extremely toxic when inhaled.

- anyone who transports in bulk packaging, if the bulk packaging has a capacity of at least 3500 gallons or more than 468 cubic feet.

- anyone who transports at least 5000 pounds of a hazardous material that requires placarding for vehicles, rail cars, or freight containers.

- anyone involved in the transportation of oil, gas, pesticides, or any other potentially hazardous substances should contact DOT to be sure they are complying with the law.

\section{What Are the Penalties under HMTAA?}

Anyone who knowingly violates HMTAA may be subject to fines of at least $\$ 250$, but not more than $\$ 25,000$ per day, per violation. Anyone who knowingly and willfully violates HMTAA may be fined or imprisoned for up to 5 years under the criminal provisions.

\section{Acknowledgments}

The authors are indebted to the personnel of both state and federal agencies who gave their time and advice in the preparation of this handbook. The authors are also indebted to the following University of Florida personnel for a review and critique of the first draft of this publication: Dr. Thomas Dean, Pesticide Education Specialist, and Dr. Norman Nesheim, Pesticide Information Coordinator. Special recognition is also due to $\mathrm{Mr}$. Richard Budell of the Office of Agricultural Water Policy of the Florida Department of Agriculture and Consumer Services for providing funds for the development of this handbook.
This handbook is designed to provide an accurate, current, and authoritative summary of the principal Florida laws that directly or indirectly relate to agriculture. It should provide a basic overview of the many rights and responsibilities farmers and farmland owners have under Florida laws. The reader is provided information about these rights and responsibilities and the appropriate contacts for more detailed information. However, the reader should be aware that because the laws, administrative rulings, and court decisions on which this publication is based are subject to constant revision, portions of this publication could become outdated at any time. Many details of cited laws are also left out due to space limitations.

This handbook is distributed with the understanding that the authors are not engaged in rendering legal or other professional advice and the information contained herein should not be regarded or relied upon as a substitute for professional advice. It is not all-inclusive in providing information to achieve compliance with laws and regulations governing the practice of agriculture. For these reasons, the use of these materials by any person constitutes an agreement to hold harmless the authors, UF/IFAS, the Agricultural Law Center, and the University of Florida for any liability claims, damages, or expenses that may be incurred by any person as a result of reference to or reliance upon the information contained in this publication. 